\title{
ЗОЛОТУШНИК КАНАДСЬКИЙ
}

\section{Solidago canadensis L. - потенційний біоремедіатор забруднених трунтів}

\begin{abstract}
Мета. Визначити закономірності забруднення прилеглих до автомобільної траси Київ - Одеса територій трунту і специфіку поглинання дикими рослинами (золотушника кандського Solidago Canadensis L.) полютантів. Методи. Польові та лабораторні. Результати. У продук-

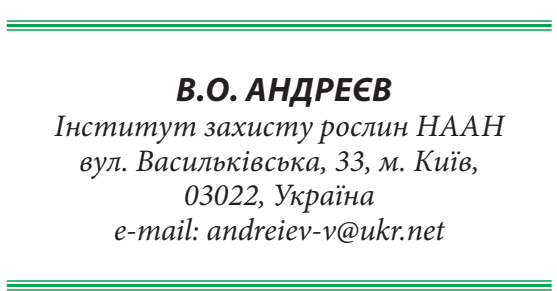
тах горіння автомобільних двигунів, що рухаються по автостраді, присутні різні хімічні сполуки, у тому числі і метали - свинець (Рb), хром (Cr), кобальт (Со), та інші. У зразках трунту, взятих на відстані 5 м від автостради, присутність сполук свинцю становила 11,401мг/кг, сполук хрому - 19,361 мг/кг. На відстані 1280 м від полотна автостради у грунті було сполук свинию 6,845 мг/к2, сполук хрому - 5,376, кобальту - 0,271 мг/ке. У надземних частинах рослин золотушника канадського (листки, стебла) найвища концентрація сполук зафіксована у зразках, які були відібрані на відстані 5 м від автотраси: свинию - 5,136 мг/кг., хрому - 6,366, кобальту - 3,158 мг/кг. На відстані 5 м від автостради у підземних частинах рослин, які є багаторічними органами, концентрація сполук свинию досягала 2,763 мг/кг, сполук хрому - 3,642, кобальту - 2,034 мг/кг. На відстані від автостради $1280 \mathrm{м}$ фіксували у листках золотушника канадського концентрацію сполук свинию в середньому 2,675 мг/кг, шо менше порівняно з показниками біля автостради (відстань 5 м) в 1,92 раза, сполук хрому - 1,614 (у 3,94 раза менше порівняно з максимальним накопиченням у дослідах), сполук кобальту - 0,165 мг/кг (у 19,1 раза менше). Висновки. Накопичення сполук важкки металів у надземних частинах рослин (листках і стеблах) золотушника канадського, шо росте біля дороги, більше (свинцю в 1,86 раза, хрому в 1,75, кобальту в 1,55 раза) порівняно з підземними багаторічними частинами рослин. Результати досліджень доводять доцільність практичного використання золотушника канадського в якості біоремедіа- тора забруднених грунтів територій, прилеглих до автомобільних доріг 3 інтенсивним рухом, і можливостей його раціонального практичного господарського застосування.

важкі метали, забруднення, грунт, рослини

Господарська діяльність людини традиційно руйнує природне біологічне різноманіття в регіонах. Значним забруднювачем є автомобільний транспорт. Робота двигунів внутрішнього згоряння призводить до забруднення не лише полотна автомобільних доріг, адже повітряні потоки переносять продукти згоряння палива на прилеглі до автомобільних доріг території. у загальному техногенному забрудненні атмосфери (за показниками маси) внесок транспортних засобів досягає $60 \%$ (енергетика $10-15 \%$, металургія - 30-20\%). Серед всіх джерел антропного забруднення довкілля транспорт перевищує енергетику та металургію в 3-4 рази [1, 2].

Сам рух транспорту призводить до формування конвекційних потоків приземного шару повітря, які підхоплюють вихлипні гази від двигунів внутрішнього згоряння та пилові частки з полотна дороги на висоту кількох метрів, де їх легко підхоплюють потоки вітру і переміщують на значні відстані.

За даними ООН густота доріг становить один кілометр дороги на 4,2 км² території (ділянка земної поверхні $650 \times 6500$ м). У процеci будівництва нових доріг площа таких ділянок зменшується [3-5].

Робота автомобільного транспорту призводить до значних ви- трат природних ресурсів, у першу чергу вільного кисню атмосфери. Відновлення ресурсів у природі традиційно доволі тривале: біосфера -8 років, фітосфера -14 років [6]. А деструктивний антропний вплив на довкілля постійно зростає. В результаті господарської діяльності рівень запиленості атмосфери за останні 50 років підвищився на $70 \%$.

Автотранспорт забруднює довкілля водночас різними факторами впливу: дією вихлипних газів двигунів внутрішнього згоряння, пилом, звуковим впливом, тепловим забрудненням. У великих містах з потужним автомобільним парком найбільш інтенсивне забруднення довкілля становлять сполуки $\mathrm{Fe}, \mathrm{Pd}, \mathrm{Zn}, \mathrm{Cu}, \mathrm{Cr}, \mathrm{V}, \mathrm{Ni}$, Cd. İз органічних сполук поширені пірен, фенантрен, аценаптален, флуораптен [7, 8]. Крім газових викидів більш небезпечними $\epsilon$ тверді часточки вихлипних газів двигунів: мікрочастки сажі, озон, чадний газ, оксиди сірки. Наночастки (1-300 н.м.) мають високу площу поверхні, проявляють токсичність, канцерогенність, мають адгезійні, сорбційні властивості.

У забрудненні, яке створює автотранспорт у процесі роботи, найбільшу частку складають оксид вуглецю (чадний газ) - 57,7\%, оксиди азоту $(\mathrm{N})-26,9 \%$, частка сполук вуглеводнів - 15,7\%. Обсяги таких забруднень дуже великі. Наприклад, протягом року у м. Казань (РФ) автотранспорт продукує вуглекислого газу $\left(\mathrm{CO}_{2}\right)-684$ тис.т, закису азоту $\left(\mathrm{NO}_{2}\right)-2,5$ тис.т, метану $\left(\mathrm{CH}_{4}\right)-$ 2,2 тис.т [9].

Оксиди азоту у 10 разів більш небезпечні для людини порівняно 3 чадним газом (CO). Від 4 до $5 \%$ у загальному обсязі токсичності вихлипних газів автотранспорту становлять різні форми альдегідів. Ненасичені вуглеводні в присутності $\mathrm{NO}_{2}$ фотохімічно окислюються і формують отруй- 
ні сполуки, що містять кисень смог. Поліциклічні ароматичні вуглеводні - це сильні канцерогени. Серед них бенспірен, похідні антрацену: 1,2-бензантрацен, 1,2,6,7-дебензантрацен, 5,10-диметил-1,2бензантрацен. Крім них сполуки сірки (S), тетраетил свинцю $(\mathrm{Pb})$, сполуки брому, хлору та інших речовин [10].

Вихлипні гази автомобілів можуть бути причиною проблем дихання, гаймориту, ларинготрахеїту, бронхіту, бронхопневмонії, раку легень, порушень роботи серцевосудинної системи, атеросклерозу судин головного мозку. Частина такого техногенного забруднення розсіюється в атмосфері, частина осідає на рослинність і надходить у орний шар грунту $[11,12]$.

Відбувається поступове накопичення таких речовин і їх включення у біологічний кругообіг природи, що створює екологічну загрозу.

У 1970 р. Європейська грунтова хартія визначила, що будь яка біологічна, фізична або хімічна деградація грунтів є першочергово небезпечною і відповідні заходи для захисту грунтів мають бути здійснені негайно. Тільки в країнах СС на початку 21 століття $€ 1,5$ млн га забруднених ділянок, на очищення яких необхідно понад 85 млрд євро. За кожні 10 років необхідність відновлення забруднених грунтів зростає в 3 рази. У 2000 році в країнах ЄС на очищення грунтів витратили 9 млрд євро, за потреби 85 млрд [13, 14].

Природа здатна протистояти техногенному забрудненню перш за все шляхом біоремедіації грунтів. Процеси очищення забруднених грунтів відбуваються відносно повільно. Здатність рослин до біологічної акумуляції токсикантів визначають коефіцієнтом біологічного накопичення - відношення концентрації токсиканта в рослині і його концентрації в грунті.

Гіперакумулятори здатні поглинати наявні сполуки металів у кількості, що становить кілька відсотків від сухої маси.

Трав'янисті рослини застосовують для фітостабілізації забруднень: зменшення їхньої рухливості в орному шарі за рахунок адсорбції або осадження на поверхні коренів у формі нерозчинних сполук (фосфатів, карбонатів, гідроксилів і т. д.). Бажано щоб це були рослини, які формують щільний трав'янистий покрив і здатні зв'язувати полютанти в процесі обміну речовин $[15,16]$.

Процеси поглинання, акумуляція полютантів та їхня трансформація найбільш характерні для частин у рослин, що здатні періодично відмирати і опадати: листки, надземні стебла у трав'янистих рослин $[17,18]$.

Метою досліджень було визначення закономірностей забруднення прилеглих до автомобільної траси Київ-Одеса територій грунту i специфіки поглинання дикими рослинами (золотушником канадським Solidago canadensis L.) полютантів та можливості їхнього оздоровлення.

Умови та методи дослідження. Дослідження були проведені у 2016-2019 рр. на орних землях у Васильківському районі Київської області, що безпосередньо прилягають до автотраси Київ - Одеса. Грунт полів, де відбирали зразки грунту і рослин пирію для аналізів, темно-сірий опідзолений, середньо суглинковий на карбонатному лесі, типовий для північної частини Лісостепу України.

Облікові ділянки площею 25 м $^{2}$ у 4-разовій повторності розмішували на відстані від полотна автомобільної дороги: 5 м, 10 м, 20 м, 40 м, 80 м, 160 м, 320 м, 640 м, 1280 м. Зразки грунту і рослин пирію повзучого відбирали в 5-ти точках на ділянках кожного повторення. Зразки грунту відбирали 3 орного шару $0-10 \mathrm{~cm}$, по 2 кг у кожному повторенні.

Надземні частини рослин відділяли від підземних багаторічних частин (кореневищ) і після ретельного перемішування відбирали середній зразок масою 1 кг. І̇з рослинних зразків відбирали наважки (100 г на кожне повторення) і висушували у сушильній шафі протягом доби за температури $116^{\circ} \mathrm{C}$.

Аналіз вмісту в сухому рослинному матеріалі важких металів проводили в Їнституті фізіології та генетики НАН України. Визначення елементного складу в дослідних зразках здійснювали методом İCP-MS на емісійному мас-спектрометрі Agilent 7700x. Зразки сухої маси озолювали в азотній кислоті (осч) за допомогою мікрохвильової пробопідготовки MilestoneStart D. Отрима- ний екстракт доводили до об'єму 50 мл водою 1-го класу (18 Мом), підготовленою на системі очищення води Scholar - UV NexUp 1000 (HumanCorporation, Корея).

Результати дослідів опрацьовували статистично згідно зі стандартними методиками [19], за допомогою програми Exel та з математичною обробкою одержаних даних за допомогою професійного пакету програм для статистичного аналізу Statistica 8,0.

Результати досліджень. Трав'яниста рослина золотушник канадський Solidago canadensis L. $€$ багаторічником, що здатний формувати велику надземну масу і площу листкової поверхні, яка здатна зв'язувати і частково поглинати полютанти від автотраси, надійно захищати грунт прилеглих територій від водної ерозії. Перевагою рослин золотушника канадського є та особливість, що вона дикоросла, іiі практично не поїдають травоїдні тварини, тому переміщення полютантів від автотраси по трофічних ланцюгах легко можна локалізувати. Позитивною особливістю рослин такого виду $є$ їхня здатність довго перебувати у періоді цвітіння, формувати значні обсяги нектару, який є екологічно безпечним і може бути джерелом одержання якісного меду медоносними бджолами. Надземна маса рослин золотушника канадського $€$ перспективною для виробництва біоененргетичної маси, що має високу теплотворну здатність. Спалювання такого забрудненого важкими металами твердого біопалива вимагає невеликої адаптації котельні: пилові димові фільтри і захоронення продуктів спалювання (попелу) у безпечних місцях.

Відбір зразків грунту і рослин золотушника канадського в роки досліджень здійснювали у третю декаду серпня. На час відбору зразків рослини золотушника канадського перебували в сенільному етапі органогегезу. Надземна маса рослин після тривалого періоду цвітіння формувала насіння і закінчувала свою вегетацію. Рух повітря у приземному шарі атмосфери, до якого регулярно надходять продукти горіння автомобільного палива у формі газів та аерозолів, переносить їх згідно 3 «розою вітрів» на території, що прилягають до автотраси.

Полютанти від полотна дороги 
поступово осідають на поверхню грунту прилеглих територій і потім надходять у орний шар, частково осідають на поверхню надземних частин рослин, що вегетують на таких територіях. У продуктах горіння автомобільних двигунів, що рухаються по автостраді, присутні різні хімічні сполуки, у тому числі і металів - свинець $(\mathrm{Pb})$, хром $(\mathrm{Cr})$, кобальт(Со), та інших. Названі хімічні елементи належать до «важких металів» і за значної присутності здатні проявляти негативний вплив на процеси життєдіяльності організмів людей, тварин і рослин.

Результати досліджень вмісту важких металів у зразках грунту i рослин золотушника канадського, взятих біля автотраси Київ-Одеса (2016-2019 pp.), наведено у таблиці.

Визначення вмісту сполук свинцю $(\mathrm{Pb})$ у зразках грунту виявило певні закономірності їхнього накопичення. Найвищі показники присутності сполук свинцю в орному шарі грунту $(0-30 \mathrm{~cm})$ були зафіксовані на відстані 5 м від автостради.

В середньому за роки досліджень концентрація сполук свинцю становила 11,402 мг/кг. Зі збільшенням дистанції відбору зразків від полотна автостради до 20 м фіксували зниження концентрації сполук свинцю в зразках грунту до 8,205 мг/кг. На відстані 80 м від джерела забруднення (автостради), концентрація сполук свинцю становила 7,355 мг/кг. На дистанції 320 м у орному шарі концентрація сполук свинцю станови- ла 7,354 мг/кг. На максимальній у дослідах відстані відбору зразків грунту - 1280 м концентрація сполук становила 6,845 мг/кг, або $60 \%$ від максимального. Одержані показники є результатом багаторічного впливу забруднювачів полютантів від полотна автотраси на прилеглі території і поступового накопичення сполук свинцю в орному шарі грунту.

Присутність сполук свинцю (Pb) в рослинах, що активно вегетують, істотно відрізняється від величин накопичення у орному шарі грунту. Надходження сполук свинцю $(\mathrm{Pb})$ в рослини золотушника канадського відбувалось двома основними шляхами: через систему коренів 3 грунту і через надземні (однорічні) частини. Стебла і листки рослин отримували забруднення переважно в результаті транслокації потоками повітря. Надходження сполук свинцю відбувається переважно внаслідок фізичної дифузії із довкілля в цитоплазму живих клітин рослин.

У надземних частинах рослин золотушника канадського (листки, стебла) найвищу концентрацію зафіксовано у зразках, що були відібрані на відстані 5 м від автотраси, і вона становила в середньому 5,136 мг/кг. У підземних частинах рослин, які є багаторічними органами, концентрація сполук свинцю $(\mathrm{Pb})$ була істотно нижчою - 2,763 мг/кг.

За збільшення відстані відбору зразків від автостради до 80 м аналіз фіксував зниження концентрації сполук свинцю в надземних час-

Вліст важких леталів у трунті і рослинах золотуиника канадського (мг/кг) біля автотраси Київ - Одеса 2016-2019 рр.

\begin{tabular}{|l|c|c|c|c|c|}
\hline \multirow{2}{*}{ Місце відбору проб } & \multicolumn{5}{|c|}{ Відстань від полотна дороги, $\mathbf{~}$} \\
\cline { 2 - 6 } & $\mathbf{5}$ & $\mathbf{2 0}$ & $\mathbf{8 0}$ & $\mathbf{3 2 0}$ & $\mathbf{1 2 8 0}$ \\
\hline \multicolumn{5}{|c|}{$\mathbf{P b}$} \\
\hline У грунті & 11,401 & 9,372 & 7,355 & 7,162 & 6,845 \\
\hline Наздемні частини рослин & 5,136 & 4,197 & 3,193 & 2,974 & 2,675 \\
\hline Підземні частини рослин & 2,763 & 2,671 & 2,184 & 1,781 & 1,181 \\
\hline \multicolumn{5}{|c|}{ Cr } \\
\hline У грунті & 19,361 & 18,193 & 16,989 & 11,347 & 5,376 \\
\hline Наздемні частини рослин & 6,366 & 5,524 & 4,312 & 3,263 & 1,614 \\
\hline Підземні частини рослин & 3,642 & 3,165 & 2,285 & 1,562 & 0,543 \\
\hline \multicolumn{5}{|c|}{ Со } \\
\hline У грунті & 3,895 & 3,358 & 2,795 & 1,138 & 0,271 \\
\hline Наздемні частини рослин & 3,158 & 2,781 & 1,839 & 1,304 & 0,165 \\
\hline Підземні частини рослин & 2,034 & 1,793 & 1,258 & 0,797 & 0,087 \\
\hline \multicolumn{5}{|c|}{ Нір 0,05} & 0,026 \\
\hline
\end{tabular}

тинах рослин золотушника канадського в середньому до 3,193 мг/кг, що на $37,8 \%$ менше максимальних показників. У підземних частинах рослин присутність сполук свинцю $(\mathrm{Pb})$ становила $2,184 \mathrm{Mг} / \mathrm{Kг,} \mathrm{тобто}$ знижувалась на 20,9\% від максимальних показників у дослідах. Порівняно з надземними частинами рослин концентрація сполук свинцю у багаторічних підземних була в 1,46 раза меншою.

Аналізи зразків рослин золотушника канадського, які відбирали на максимальній у дослідах дистанції від автостради - 1280 м, фіксували у надземних частинах концентрацію сполук свинцю в середньому 2,675 мг/кг, що менше порівняно 3 показниками біля автотраси (відстань 5 м) у 1,92 раза. У підземних багаторічних частинах рослин концентрація сполук свинцю $(\mathrm{Pb})$ становила 1,181 мг/кг зменшення на $57,3 \%$.

Специфічною виявилась закономірність розподілу концентрації у грунті і рослинах золотушника канадського потенційно небезпечних для довкілля сполук хрому ( $\mathrm{Cr}$ ). Найвища концентрація сполук хрому у орному шарі була зафіксована безпосередньо біля автостради (на відстані 5 м). За роки досліджень вона становила в середньому 19,361 мг/кг грунту. І̇з збільшенням відстані відбору проб грунту для аналізів до $80 \mathrm{M}$ фіксували зменшення присутності сполук хрому до 16,989 мг/кг - на 12,3\% порівняно з максимальною концентрацією в дослідах.

На відстані від автостради 320 м у пробах грунту було встановлено присутність сполук хрому (Cr) в кількості 11,347 мг/кг, тобто зниження концентрації сполук хрому, порівняно з максимальними показниками, становило 41,4\%. У пробах грунту, які відбирали на максимальній у дослідах відстані від автостради - $1280 \mathrm{M}$, кількість сполук хрому була в середньому 5,376 мг/кг. Отже рівень накопичення сполук такого важкого металу був меншим за концентрацію біля автостради (на відстані 5 м) у 3,6 раза.

Присутність сполук хрому (Cr) в тканинах рослин золотушника канадського відрізнялась від показників концентрації у орному шарі грунту. У надземних частинах рослин (стебла та листки) найвища концентрація сполук важкого металу була 
зафіксована у пробах, видібраних на відстані 5 м від автотраси. В середньому за роки досліджень вона становила 6,366 мг/кг. Збільшення відстані відбору зразків від джерела забруднення (полотно дороги) фіксувало зниження концентрації присутності техногенних речовин у приземних потоках повітря і відповідно зниження рівня забруднення сполуками хрому $(\mathrm{Cr})$ надземних частин рослин, що там вегетують.

У пробах, які відбирали на відстані 80 м, концентрація сполук хрому (Cr) становила 4,312 мг/кг, або порівняно з максимальним рівнем присутності у дослідах менша на 32,3\%. Збільшення відстані від джерела забруднення до місця відбору проб до 320 м забезпечувало зниження рівня накопичення в надземних частинах рослин сполук хрому до 3,263 мг/кг.

На максимальній у дослідах відстані 1280 м концентрація сполук хрому у надземних частинах рослин золотушника канадського була найменшою - 1,614 мг/кг. Відповідно збільшення дистанції від джерела забруднення в результаті розсіювання техногенних речовин на великій площі призводить до зниження рівня забруднення довкілля сполуками хрому у 6,71 раза порівняно 3 максимальним накопиченням у дослідах у надземних частинах рослин золотушника канадського.

Підземні частини рослин золотушника канадського є багаторічними і процеси накопичення сполук важких металів, у тому числі i хрому $(\mathrm{Cr})$, в них рослина обмежує. У підземних частинах рослин концентрація сполук хрому, була істотно меншою порівняно 3 показниками накопичення такого забруднювача у орному шарі грунту. Найвищі показники концентрації сполук хрому в підземних частинах рослин золотушника канадського були зафіксовані в пробах, відібраних біля автотраси (відстань 5 м) - в середньому 3,642 мг/кг. На відстані 80 м показники концентрації сполук хрому були меншими і досягали 2,285 мг/кг - 37,3\% від максимальної концентрації.

Збільшення відстані від джерела забруднення (автотраса) до 320 м призводило до зменшення інтенсивності забруднення і відповідно концентрації сполук важкого металу в підземних частинах рос- лин (1,562 мг/кг) на 57,1\% максимальних у дослідах показників.

На відстані від джерела забруднення 1280 м середні показники концентрації сполук хрому $(\mathrm{Cr})$ в тканинах підземних частин рослин становили в середньому 0,543 мг/кг. Тобто із зростанням відстані від автостради інтенсивність накопичення сполук важкого металу в підземних частинах рослин знижувалась у 6,71 раза порівняно із максимальними показниками накопичення у дослідах.

3 хімічних елементів, забруднення сполуками яких досліджували, найменші показники концентрації в орному шарі грунту були зафіксовані у кобальту (Со). На відстані в 5 м від автостради зразки грунту містили в середньому 3,895 мг/кг сполук кобальту, або це величина менша порівняно з присутністю сполук хрому $(\mathrm{Cr})$ в 4,9 раза. Збільшення відстані відбору зразків грунту до 80 м фіксувало зниження концентрації сполук кобальту в орному шарі до 2,795 мг/кг, що на 42,5\% менше порівняно 3 максимальною концентрацією сполук Со в дослідах.

На відстані 320 м від автотраси у зразках грунту було встановлено наявність сполук кобальту (Co) в середньому 1,138 мг/кг. На максимальній у дослідах відстані відбору зразків - 1280 м концентрація сполук Со була найнижчою - 0,271 мг/кг, або у 1,19 раза меншою порівняно 3 максимальними показниками в дослідах.

Специфічним виявився розподіл сполук кобальту в частинах рослин золотушника канадського, які відбирали для аналізів. У надземних частинах (листках, стеблах) рослин найвищі показники концентрації сполук кобальту зафіксовані у зразках, відібраних на відстані 5 м від автостради. Вони становили в середньому 3,158 мг/кг.

На відстані 80 м від автотраси у зразках надземних частин рослин золотушника канадського концентрація сполук кобальту становила 1,839 мг/кг, що у 1,72 раза менше порівняно з найвищою у дослідах. За збільшення відстані відбору зразків рослин до 320 м аналізи фіксували присутність сполук кобальту 1,304 мг/кг, або наступне зниження концентрації полютанту.

На максимальній у дослідах відстані відбору зразків 1280 м концентрація сполук кобальту в листках і стеблах рослин золотушника канадського була найменшою і становила в середньому за роки проведення досліджень 0,165 мг/кг. Відповідно збільшення відстані від джерела забруднення (автотраси) до 1280 м зменшувало рівень концентрації сполук кобальту у 2,99 раза від максимального в дослідах.

На відстані 80 м від автотраси у підземних частинах рослин золотушника канадського концентрація сполук кобальту досягала 1,258 мг/кг - менше порівняно 3 показниками концентрації у листках і стеблах на $31,6 \%$.

Збільшення відстані від джерела забруднення (полотно дороги) до 320 м забезпечувало зменшення показників концентрації сполук кобальту у підземних частинах рослин золотушника канадського до 0,797 мг/кг, а на максимальній у дослідах відстані відбору зразків для аналізів - 1289 м, концентрація полютанту становила 0,087 мг/кг, що у 23,4 раза менше порівняно $з$ максимальними показниками у дослідах.

\section{ВИСНОВКИ}

Найвищі показники концентрації важких металів - продуктів згоряння автомобільних двигунів (сполуки свинцю $(\mathrm{Pb})$, хрому $(\mathrm{Cr})$, кобальту (Со)) - у грунті і рослинах золотушника канадського зафіксовано на відстані до 80 м від автотраси. Зниження концентрації полютантів у результаті перемішування аерозолів з повітрям призводить до зменшення концентрації у зразках грунту на відстані 320 м від автотраси у орному шарі грунту сполук свинцю у 1,5; хрому в 1,7, кобальту в 3,4 раза.

На максимальній відстані від автотраси - 1280 м вміст сполук важких металів у грунті становив: свинцю - 6,845 мг/кг, хрому 5,376; кобальту - 0,271 мг/кг, що відповідно у 1,7; 3,6 та 14,4 раза менше від максимальних показників у дослідах.

Розподіл сполук важких металів у надземних частинах рослин золотушника канадського біля дороги виявив певні закономірності концентрації: свинцю в 1,86 раза, хрому в 1,75 , кобальту в 1,55 раза більше накопичувалось у надземних частинах (листках і стеблах) порівняно з підземними багаторічними. 
Результати досліджень накопичення сполук важких металів у надземних однорічних частинах рослин золотушника канадського доводять доцільність практичного використання рослини в якост біоремедіатора забруднених грунтів територій, прилеглих до автомобільних доріг з інтенсивним рухом, і можливостей іiі раціонального практичного господарського застосування.

\section{ЛІТЕРАТУРА}

1. Донченко В.В., Кунин Ю.И., Руз ский А.В., Виженский В.А. Методы расчета выбросов от автотранспорта и результаты их применения. Журнал автомобильных инженеров. 2014. Т. 86, № 3. С. 44-51.

2. Mastrofrancensco A., Alfe M., Rosato E. et. al. Proinfalammatory effects of diesel exhaus nanoparticles on sclrodennascin cells. Journal of Immunology Research. 2014. Vol. 20.

3. Kam W., Liacos J.W., Schauer I.J., et. al. Sizesegregated composition of particulate matter (PV) in major roadways and surface streets Atmospheric Environment. 2012. 55. P. 90-97.

4. Голохвост К.С., Чернышев В.В., Угай С.М. Выбросы автотранспорта и экология человека. Экология человека. Владивосток. 2016. № 1. C. 9-14.

5. Половинкина Ю.С. Шумовое загрязнение окружающей среды урбанизированных территорий (на примере города Волгограда) Научный журнал Куб ГАУ. 2012. № 76, (02) C. $1-10$.

6. Di Lorio S., Magno A., Manganiso E. et. al. Engine performance and emissions of a smal diesel engine fueled with various diesel. RME blends. SAE: Technical Paper. 2014.

7. Ведение сводного тома предельно допустимых выбросов в атмосферу г. Казани. Отчет по государственному контракту № 15МЭ. от 05.10. 2015 г. Казань: ИПЭН, АН PT, 2015. $264 \mathrm{c}$.

8. Анбимов В., Гольдман Е. Автотранспорт и экология городов Израиля. Иерусалим. 2012. 174 с.

9. Mathissen M., Scheer V., Kirchner U. et. al. Non-exhaust PM emission measurements of a light duty vehicle with a mobile trailer. Atmospheric Environment. 2012. Vol. 59. P. 232-242.

10. Щербаченко O.I. Важкі метали як токсичний фактор забруднення природного се редовища. Стійкість і адаптація рослин до їх впливу. Наукові записки Державного природознавчого музею. Інститут екології Карпат НАН України. Львів, 2014. Вип. 30. С. 157-182.

11. Янкевич М.И., Хадеева В.В., Мурьги на В.П. Биоремедиация почв: вчера, сегодня, завтра. Междисииплинарный научный и прикладной журнал «Биосфера» 2015, т. 7, №2. C. 198-208.

12. Антонюк Н.О., Гриценко Н.А. Шляхи очищення довкілля від забруднення важкими металами. Наукові праці НУХТ. 2014, том. 20. №5. C. $15-27$.

13. Wang J., Pui D.Y.H. Dispersion and filtration of carbon nanotubes (CNTS) and measurement of nanoparticle agglomerates in diesel exhaust. Chemical Engineering Science. 2013. Vol. 85. P. 69-76.

14. Lanrish J.P., Unosson J., Bosson U. et.al. Altered nitric oxide bioavailability contributes to diesel exhaust inhalation - induced cardio- vascular dysfunction in man. J. Am. Heart Assjc. 2013. Vol. 2(1)

15. Суравегина И.Т., Сенкевич В.Г. Как учить экологии. Москва: Просвещение, 1995. $96 \mathrm{c}$.

16. Егорова А.В., Мамонтова В.Н, Абти И.А., Никифоров В.А., Янкевич М.И. Жаковская 3.А. Бактериальная деградация полициклических ароматических углеводородов в городских почвах. Известия СанктПетербургского государственного технологического института. 2014. (23). С. 75-78.

17. Джувеликян Х.А., Щеглов Д.И., Горбунова Н.С. Загрязнение почв тяжелыми металлами. Способы контроля и нормирования загрязненных почв. Изд. полиграф центр Воронежского гос. Университета, 2009. 21 с.

18. Davidson C.I., Osborn J.F. The sizes of airborne trace metal-containing particles. Nriagu J.O. \& Davidson C.I. (Eds). Toxic metals in the atmosphere. New York: Wilei, 1986. P. 355-390.

19. Эрмантраут Э.Р. Статистический анализ многофакторных экспериментов. Полевые эксперименты для устойчивого развития сельской местности. Санкт-ПетербургПушкин, 2003. С. 70-73.

\section{Андреєв B.A.}

Институт защиты растений НАAН, ул. Васильковская, 33, г. Киев, 03022, Украина, e-mail: andreiev-v@ukr.net

\section{Золотарник канадский}

Solidago canadensis L. -

потенциальный биоремедиатор загрязненных почв

Цель. Определить закономерности загрязнения прилегаюших к автомобильной трассе Киев - Одесса территорий почвы и спечифику поглощения дикими растениями (золотарником канадским Solidago canadensis L.) поллютантов. Методы. Полевые и лабораторные. Результаты. В продуктах горения автомобильньх двигателей, движущихся по автостраде, присутствуют различные химические соединения, в том числе и металль - свинеи $(\mathrm{Pb})$, хром (Cr), кобальт (Со), и другие. В образиах почвы, взятых на расстоянии 5 м от автострады, присутствие coeдинений свиниа составляло 11,401 м2/к2, соединений хрома - 19,361 мг/к2. На расстоянии 1280 м от полотна автострады в почве было соединений свиниа 6,845 м2/к2, соединений хрома - 5,376, кобальта 0,271 мг/кг. В надземных частях растений золотарника канадского (листья, стебли) высокая концентрация соединений была забиксирована в образиах, которье были отобраны на расстоянии 5 м от автотрасcbl: свинияа - 5,136 мг/к2, хрома - 6,366, кобальта - 3,158 мг/к2. На расстоянии 5 м от автострады в подземных частях растений, которые являются многолетними органами, концентрация соединений свиниа достигала 2,763 мг/кг, соединений хрома - 3,642, кобальта - 2,034 мг/кг. На расстоянии от автострады 1280 м фиксировали в листьях золотарника канадского кониентрацию соединений свиниа в среднем 2,675 мг/к2, что меньше по сравнению с показателями у автострады (расстояние 5 м) в 1,92 раза, соединений хрома - 1,614 (в 3,94 раза меньше по сравнению с максимальным накоплением в опьтах), соединений кобальта - 0,165 мг/к2 (в 19,1 раза меньше). Выводы. Накопления соединений тяжельх металлов в надземных частях растений (листьях и стеблях) золотарника канадского, что растет возле дороги, выне (свиниа в 1,86 раза, хрома в 1,75, кобальта в 1,55 раза) по сравнению с многолетними подземными частями растении. Результать исследований доказывают иелесообразность практического использования золотарника канадского в качестве биоремедиатора загрязненных почв территорий, прилегаюших к автомобильным дорогам с интенсивным движением, и возможностей его рационального практиче ского хозяйственного применения.

тяжелые металлы, загрязнение, почва, растения

\section{Andreiev V.}

Institute of Plant Protection of NAAS, 33, Vasylkivska str., Kyiv, 03022, Ukraine, e-mail:andreiev-v@ukr.net

\section{Solidago canadensis L. - potential bioremeditor of contaminated soil}

Goal. To determine the patterns of contamination adjacent to the motor road Kyiv Odesa territories of the soil and the specificity of uptake by wild plants (zolotarnica canadian Solidagocanadensis L.) pollutants. Methods. Field and laboratory studies. Results. The products of combustion of car engines moving along the freeway, there are a variety of chemical compounds, including metals - lead $(\mathrm{Pb})$, chromium $(\mathrm{Cr})$, cobalt $(\mathrm{Co})$, and others. In soil samples taken at a distance of $5 \mathrm{~m}$ from the motorway, the presence of lead compounds was $11.401 \mathrm{mg} / \mathrm{kg}$, chromium - $19.361 \mathrm{mg} / \mathrm{kg}$. At a distance of $1280 \mathrm{~m}$ from the roadway of the motorway in the soil was lead compounds $6,845 \mathrm{mg} / \mathrm{kg}$, chromium - 5.376, cobalt $0.271 \mathrm{mg} / \mathrm{kg}$ In the aboveground parts of plants of the canadian goldenrod (leaves, stems) high concentrations of the compounds were recorded in the samples that were selected at a distance of $5 \mathrm{~m}$ from the road: lead - $5.136 \mathrm{mg} / \mathrm{kg}$, chromium - 6.366, cobalt - $3.158 \mathrm{mg} / \mathrm{kg}$. At a distance of $5 \mathrm{~m}$ from the motorway in the underground parts of plants that are perennial organs, the concentration of lead compounds reached $2.763 \mathrm{mg} / \mathrm{kg}$, chromium - 3.642, cobalt $-2.034 \mathrm{mg} / \mathrm{kg}$. the distance from the motorway $1280 \mathrm{~m}$ recorded in the leaves of Canada goldenrod concentration of lead compounds in an average of $2.675 \mathrm{mg} / \mathrm{kg}$, compared with the figures from the motorway (distance 5 m) 1.92 times, chromium - 1.614 (3.94 times less compared to the maximum accumulation in the experiments), compounds of cobalt $0.165 \mathrm{mg} / \mathrm{kg}$ (in 19.1 times less). Conclusions. Accumulation of heavy metals in aerial parts of plants (leaves and stems) Canada goldenrod that grows near the road above (lead 1.86 times, 1.75 chromium, cobalt 1.55 times) compared with perennial underground parts of plants. The research results prove the feasibility of practical use of the canadian goldenrod as bioremediator contaminated soils of areas adjacent to roads with heavy traffic, and its sound practical economic use.

heavy metals, pollution, soil, plants

Р ец ен з ен т :

Макух Я.П.,

доктор сільськогосподарських наук Інститут біоенергетичних культур і иукрових буряків НААН Надійшла 25.02.2020 